\title{
Pendampingan Pendirian \\ Koperasi Simpan Pinjam dan Pembiayaan Syariah Koperasi Dana Bakti Sahabat
}

\author{
Nurul Hasanah, Silvia Rosa, Ach. Bakhrul Muchtasib \\ Program Studi Keuangan dan Perbankan Syariah \\ Jurusan Akuntansi Politeknik Negeri Jakarta \\ Jl. Prof. G.A. Sywabessy Kampus UI Depok \\ hasanah.nurul24@gmail.com, silviarozza@gmail.com, elbayan1979@yahoo.com
}

\begin{abstract}
ABSTRAK
Pengabdian masyarakat ini bertujuan sebagai sarana memberikan wawasan tentang koperasi syariah bagi Komunitas Bakti Sahabat Depok. Sekaligus memberikan pendampingan dan pemberdayaan ekonomi melalui pendirian koperasi simpan pinjam dan pembiayaan syariah. Disisi lain pengabdian masyarakat ini sebagai kontribusi nyata Politeknik Negeri Jakarta dalam hal ini program studi Keuangan dan Perbankan Syariah.

Koperasi Simpan Pinjam dan Pembiayaan Syariah (KSPPS) yang merupakan lembaga keuangan mikro (LKM) yang mampu melayani kebutuhan masyarakat pelaku usaha mikro dan kecil. Lembaga ini memfasilitasi terbangunnya kondisi (sistem, metoda, teknik dan output) terwujudnya perimbangan kekayaan yang tidak hanya berada pada segolongan masyarakat. Secara simultan, KSPPS juga menjadi wadah sinergi masyarakat dan manciptakan kearifan lokal. Kearifan local yang dimaksud adalah bagaimana menyiapkan infrastruktur pembangunan berbasis partisipasi masyarakat lokal, yang tidak memiliki ketergantungan permanen pada bantuan, baik dari pemerintah maupun yang lain. Pelaksanaan KSPPS dilakukan dengan bersandar kepada aturan syariah dan aturan koperasi yang ada selama tidak bertentangan dengan hukum syariah.

Kekuatan nilai-nilai spiritual dan sosial dari KSPPS ini menjadi kelebihan koperasi berbasis syariah dengan koperasi simpan pinjam konvensional. Dalam menjalankan program pengabdian ini akan dilakukan dengan melakukan pendekatan metode; persiapan, pembelajaran, dan pendirian koperasi simpan pinjam dan pembiayaan syariah.
\end{abstract}

Kata kunci: Pendampingan, penyuluhan, pendirian, koperasi simpan pinjam dan pembiayaan syariah, KSPPS 


\section{PENDAHULUAN}

Komunitas Bakti Sahabat adalah perkumpulan sahabat yang beranggotakan alumni UIN Syarif Hidayatullah Jakarta Fakultas Syariah Jurusan Muamalat Ekonomi Islam. Terbentuknya komunitas ini didorong oleh kepedulian bersama untuk saling membantu antar alumni dan juga membantu masyarakat luas khususnya dalam bidang ekonomi.

Komunitas ini, sebagaimana diceritakan oleh ketuanya, Muhammad Isnaini, sengaja dibentuk untuk berkontribusi di masyarakat, khususnya dalam bidang pemberdayaan dan pembinaan ekonominya. Hal tersebut disebabkan, diantaranya, melihat fakta di masyarakat yang sebagian pemenuhan kebutuhan ekonominya serba terbatas atau kekurangan. Masyarakat banyak terlibat hubungan dengan "rentenir" yang mereka sebut dengan bank keliling.

Masalah umum yang muncul pada kondisi masyarakat yang banyak bergantung dengan "bank keliling" adalah himpitan ekonomi yang semakin berat karena umumnya bunga yang diambil pada pinjaman mereka sangat tinggi. Bermula dari keprihatinan atas kondisi masyarakat tersebut Komunitas Bakti Sahabat berencana mendirikan Koperasi Simpan Pinjam dan Pembiayaan Syariah. Disamping untuk mendorong ekonomi mereka juga untuk menghindarkan masyarakat dari praktek ribawi yang secara tegas dan jelas dilarang oleh agama Islam.

Selain itu, para wirausaha kecil dan menengah dalam mengembangkan usaha mereka terkendala dengan akses permodalan. Sulit bagi mereka untuk mengajukan dana mengajukan ke perbankan. Sehingga memaksa mereka harus berhubungan dengan bank keliling tersebut yang membebankan bunga sangat tinggi, pada akhirnya bukan memberikan kesejahteraan dan berkembang usahanya namun menambah beban dan membuat penurunan usahanya.

Komunitas Bakti Sahabat, saat ini sudah melakukan gerakan untuk pembentukan koperasi, dan sudah terkumpul sebanyak 30 orang alumni sebagai pendiri dan anggota koperasi. Namun, mereka masih terkendala dengan SDM, biaya perizinan yang cukup besar, serta perlengkapan operasional koperasi.

Berkaitan dengan hal di atas komunitas bakti sahabat menentukan tujuan dari pembentukan yaitu 1] Membangun infrastruktur lembaga keuangan dan keswadayaan yang efektif bagi kegiatan sosial-ekonomi dan produktifitas komunitas masayarakat produktif, kreatif, berpenghasilan dan masyarakat pada umumnya. 2] Mewujudkan amanah pembinaan dan pemberdayaan ekonomi masyarakat dan pendayagunaan dana masyarakat. 3] Mengintegrasikan potensi dan sumber daya ekonomi masyarakat dalam meningkatkan produktivitas ekonomi dengan basis partisipasi dan kepentingan bersama. 4] Menciptakan alternatif model penanganan program pemberdayaan masyarakat yang bertumpu pada etos kerja dan produktivitas masyarakat.

Salah satu diantara indikator penting pertumbuhan kegiatan ekonomi sahabat adalah adanya pertumbuhan transaksi keuangan sebagai akibat meningkatnya nilai ekonomi (added value of economy) dari kegiatan usaha tersebut. Transaksi keuangan tersebut bisa bersifat perputaran dana (cash revolving) maupun penambahan dana karena terpenuhinya kebutuhan investasi dan atau penambahan nilai asset, dan hasil usaha dari kegiatan yang bersangkutan.

Dalam konteks program pemberdayaan sahabat, lembaga keuangan yang dimaksudkan adalah Koperasi Simpan Pinjam dan Pembiayaan Syariah (KSPPS) yang merupakan lembaga keuangan mikro (LKM) yang mampu melayani kebutuhan sahabat pelaku usaha mikro dan kecil. Disamping itu, lembaga ini juga memfasilitasi terbangunnya kondisi (sistem, metoda, teknik dan output) terwujudnya perimbangan kekayaan yang tidak hanya berada pada segolongan sahabat. Secara simultan, KSPPS juga menjadi wadah sinergi sahabat dan manciptakan kearifan lokal. Kearifan local yang dimaksud adalah bagaimana menyiapkan infrastruktur pembangunan berbasis partisipasi sahabat local, yang tidak memiliki ketergantungan permanen pada bantuan, baik dari pemerintah maupun yang lain.

Keberadaan KSPPS akan mendorong peningkatan taraf ekonomi sahabat sekitar secara bersama-sama. Pemenuhan atas kebutuhan sahabat relatif akan mudah terealisasi dengan berdirinya KSPPS, dimana KSPPS ini memfasilitasi ketersediaan dana bagi sahabat yang kekurangan/membutuhkan untuk kepentingan kehidupan mereka yang mana dana tersebut terhimpun dari sahabat yang memiliki kelebihan dana, atau setidak-tidaknya dana tersebut sementara waktu tidak terpakai. Prosesi ini memperlihatkan sahabat secara tidak langsung akan mengikatkan diri untuk saling mendukung pengembangan ekonomi mereka. 
Bermula dari realita bahwa kebutuhan sahabat untuk pemenuhan hajat mendasarnya cukup tinggi sementara upaya untuk pengembangan taraf ekonomi relatif lemah karena keterbatasan dana/modal, begitupun akses permodalan ke lembaga keuangan sangat sulit bagi sahabat kelas mikro dan kecil, sehingga mendorong beberapa tokoh sahabat untuk memfasilitasi ketersediaan dana tersebut dengan cara melibatkan partisipasi sahabat setempat dengan rencana pendirian lembaga keuangan berbentuk koperasi. Dengan lembaga koperasi ini akan sahabat secara aktif akan terlibat dan turut andil dalam pengembangan ekonomi sahabat sekitar.

Seperti yang dilakukan oleh Pengurus Komunitas Bakti Sahabat yang berada Ciputat Timur Tangerang Selatan. Mereka berupaya untuk mendirikan Koperasi Simpan Pinjam dan Pembiayaan Syariah dengan melihat realita kondisi ekonomi sahabat di tempat mereka cukup rendah pertumbuhannya. Basis sahabat yang berada disekitar mereka sebagian besar sahabat kelas bawah dan sebagian kecil kelas menengah. Sehingga untuk mendorong pertumbuhan ekonomi mereka dengan keterlibatan sahabat sekitar dibutuhkan lembaga keuangan berupa koperasi.

Komunitas Bakti Sahabat bertempat di kelurahan Cempaka Putih, Ciputat Timur, Tangerang Selatan, dimana lokasi ini berdekatan dengan Bintaro, berjarak $\pm 2 \mathrm{~km}$, dan pasar Ciputat berjarak $\pm 3 \mathrm{~km}$. Sahabat yang berada di Kampung Utan kelurahan Cempaka Putih sebagian besar adalah penduduk asli yang sudah tinggal di kampung tersebut sangat lama. Kondisi ekonomi mereka termasuk dalam kategori sahabat kelas bawah dan sebagian kelas menengah.

Melihat realita tersebut, untuk mensinergikan sahabat, antara yang memiliki dana dan yang membutuhkan dana dan agar terjadi harmonisasi hubungan sosial, Komunitas Bakti Sahabat berencana mendirikan Koperasi Simpan Pinjam dan Pembiayaan Syariah, dimana lembaga ini dimaksudkan menjadi wadah pengembangan ekonomi sahabat dan juga sebagai wadah menciptakan harmonisasi hubungan pesantren dengan sahabat. Diharapkan dengan pendirian KSPPS ini Komunitas Bakti Sahabat dapat melakukan pembinaan dan pemberdayaan ekonomi sahabat, sehingga mereka mampu berdaya taraf ekonominya.

Dengan pendirian KSPPS ini, kelompok sahabat tersebut ingin mendapatkan manfaat yang besar dalam melakukan pembinaan secara langsung dalam bidang ekonomi. Sebagaimana pengalaman beberapa sahabat di Indonesia yang telah mendirikan KSPPS untuk membina sahabat. KSPPS yang dikelola dengan baik akan memberikan 'multiflier effect' bagi sahabat sebagai stakeholders. Beberapa manfaat bagi stakeholders dapat digambarkan sebagai berikut:

Bagi masyarakat umum yang membutuhkan dana, KSPPS dapat menjadi alternatif pemenuhan kebutuhan atas lembaga keuangan. Lembaga keuangan seperti Bank dan sejenisnya, secara umum belum dapat menyentuh kebutuhan sebagian sahabat banyak, terutama di kalangan pedesaan, usaha mikro dan kecil. KSPPS akan menjadi alternatif sumber memperoleh pembiayaan, maupun tempat menyisihkan sebagian pendapatan dalam bentuk tabungan maupun simpanan/titipan. Selain manfaat ekonomi, KSPPS dapat memberikan manfaat sosial bagi sahabat, berupa peningkatan etos kerja, peningkatan rasa solidaritas dan kerjasama antar anggota sahabat.

Bagi masyarakat yang kelebihan dana KSPPS dapat menjadi alternatif investasi. Dewasa ini sektor usaha mikro, kecil dan menengah sedang menjadi pilihan pembiayaan bagi perbankan. Hal ini disebabkan karena transaksi dengan usaha kecil ternyata dianggap sangat efektif dan menguntungkan serta memiliki risiko yang relatif kecil. KSPPS dapat memposisioningkan sebagai satu sektor investasi yang menguntungkan bagi investor maupun pemilik dana.

Sementara bagi pengurus, KSPPS dapat menjadi pilihan yang tepat mewujudkan tanggung jawab sosial untuk ikut serta mendorong kemakmuran sahabat di lingkungannya. Tidak seperti program charity, model seperti ini tidak berisiko terhadap munculnya sikap merasa ingin dimanja, atau sikap ketergantungan permanen terhadap bantuan. Semua sahabat memiliki kesempatan dan peluang yang sama untuk memanfaatkan KSPPS, tanpa harus diberi secara langsung. Berbeda dengan bantuan yang bersifat karitas, semakin banyak sahabat yang harus dilayani, maka akan berakibat pada cost tinggi. Sedangkan dalam prinsip KSPPS, semakin banyak transaksi sahabat terjadi, maka akan semakin banyak peluang keuntungan yang akan diperoleh lembaga.

\section{METODE PENGABDIAN}

Dalam melaksanakan kegiatan ini akan menggunakan metode pelatihan dan pendampingan, karena metode ini dianggap paling sesuai dan efektif dalam memberikan 
pemahaman secara langsung ke sahabat. Dalam metode ini sahabat akan didampingi secara langsung, namun sebelumnya akan dilakukan pelatihan sebagai pemahaman awal sahabat secara teoritik. Berdasarkan hal tersebut, maka diperkirakan secara mendasar akan dilakukan pendampingan dengan prioritas pendirian KSPPS yakni:

- $\quad$ Kebutuhan perangkat regulasi: legalitas perijinan, AD/ART, system dan prosedur, dan bentuk regulasi lain yang terkait.

- Kebutuhan perangkat sosialisasi dan pelatihan

- Kebutuhan mitra kerja dan SDM

Untuk mendukung pencapaian prioritas kebutuhan pendirian KSPPS tersebut maka dilakukan tahapan pelaksanaan dengan:

\section{Persiapan}

Melakukan sosialisasi dan pengenalan lembaga Koperasi Simpan Pinjam dan Pembiayaan Syariah kepada sahabat. Dengan metode ini sahabat diberikan gambaran secara umum tentang KSPPS, manfaat dan keuntungannya bagi sahabat. Metode ini dengan cara diskusi baik dilakukan dengan metode seminar ataupun workshop.

\section{Pembelajaran}

Memberikan pelatihan dasar tentang operasional KSPPS, proses pendirian dan pengenalan produk KSPPS. Pada tahapan ini kegiatan difokuskan pada para calon pengurus dan pelaksana KSPPS dimana mereka yang akan terlibat secara langsung operasional KSPPS tersebut.

\section{Pendirian}

Setelah tahapan pelatihan tersebut selesai diteruskan dengan program pendampingan terkait dengan pembuatan AD/ART, formulir KSPPS, dan perlengkapan kerja lainnya yang menjadi syarat pendirian KSPPS tersebut secara legal dan terdaftar pada

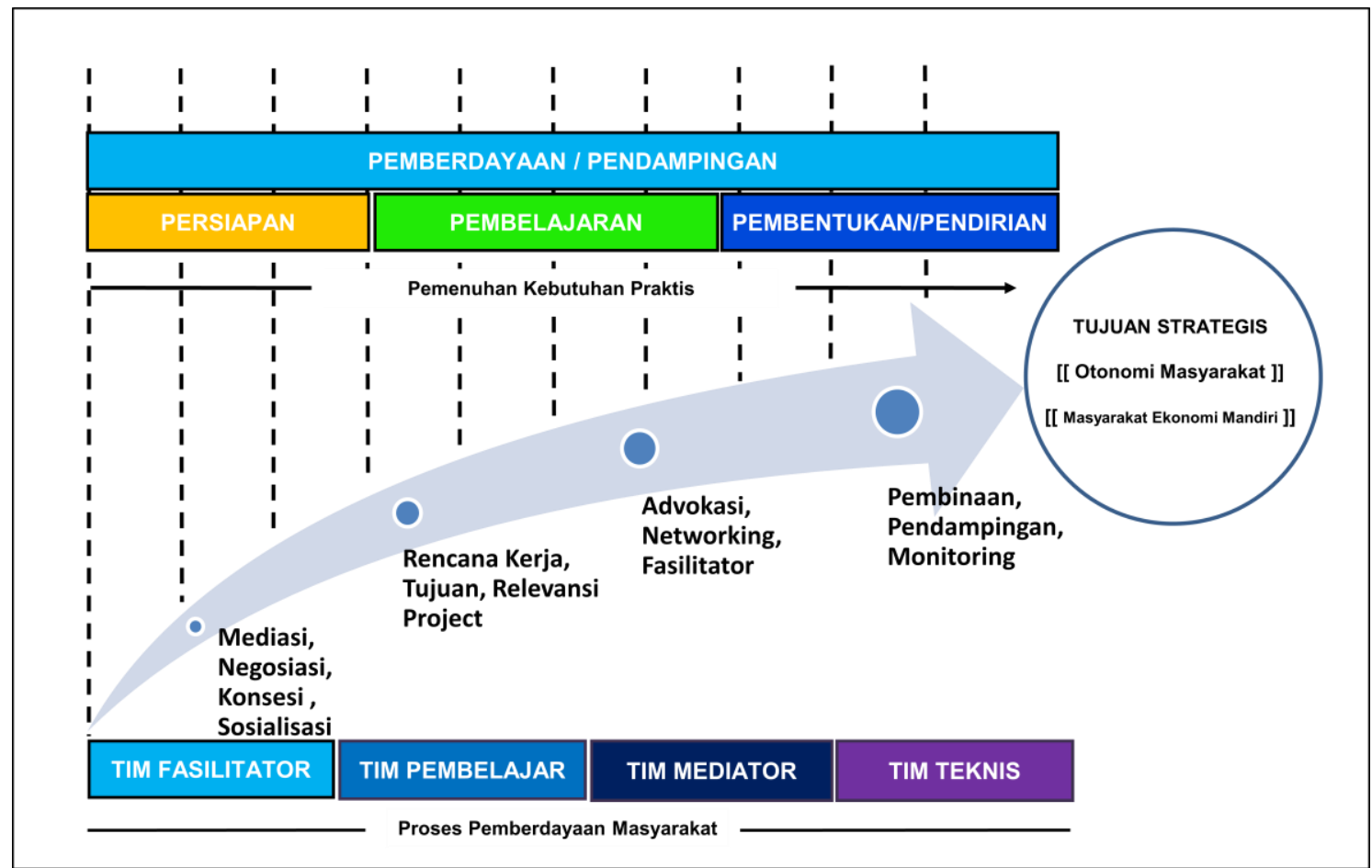

\section{HASIL DAN PEMBAHASAN}

\section{Realisasi Kegiatan}

Persiapan Kegiatan Pengabdian

Dalam melaksanakan kegiatan Pengabdian Masyarakat untuk pendampingan pendirian
Koperasi pada Komunitas Bakti Sahabat Bojongsari - Depok dilakukan beberapa tahapan persiapan, diantaranya:

1. Melakukan kordinasi dengan Ketua Komunitas Bakti Sahabat untuk mendiskusikan tentang kesiapan 
pelaksanaan Sosialisasi dan Penyuluhan koperasi ke anggota.

2. Rapat kordinasi Tim Prodi Keuangan dan Perbankan Syariah untuk menyusun jadwal kegiatan dan pembagian tugas.

3. Menentukan dan menyusun materi pendampingan yang akan disampaikan dalam kegiatan pengabdian masyarakat.

4. Menyusun kegiatan teknis pendampingan pendirian koperasi.

\section{Kegiatan Sosialisasi}

Pelaksanaan kegiatan sosialiasi untuk pendampingan pendirian Koperasi Simpan Pinjam dan Pembiayaan Syariah pada Komunitas Bakti Sahabat hari Sabtu, 25 Agustus 2018, pukul 16.00 WIB. Hadir dalam kegiatan ini para pengurus komunitas bakti sahabat yang sekaligus sebagai pengurus Koperasi Dana Bakti Sahabat. Diantaranya; Muhammad Isnaini, Romai Kurniawati, Anna Madania, Muhammad Budi Setiawan, Muhammad Ihsan, dan Kiki Priyanto.

Dalam kegiatan sosialisasi ini disampaikan bahwa kegiatan pengabdian kepada masyarakat merupakan kegiatan yang lazim dilaksanakan oleh perguruan tinggi untuk melakukan pembinaan, pendampingan, dan pemberdayaan masyarakat sebagai bentuk tanggung jawabnya melakukan pengembangan di masyarakat. Disamping itu, dalam kegiatan sosialisasi ini dijelaskan secara teknis hal-hal yang akan dilakukan selama melakukan pendampingan pendirian. Diantaranya kegiatan penyuluhan, pendampingan penyusunan draft akta notaries, dan pendampingan penyusunan anggaran dasar dan anggaran rumah tangga.

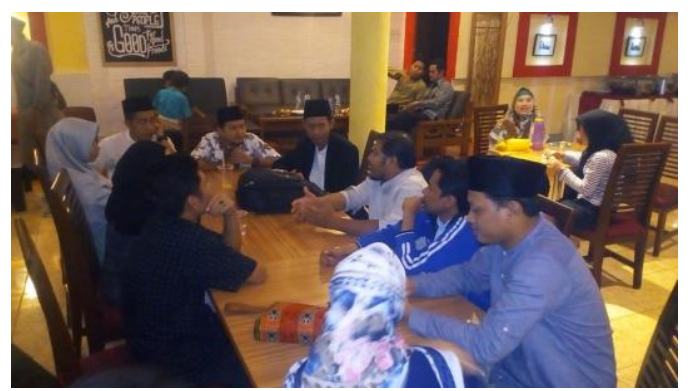

Gambar 1. Sosialisasi kegiatan Pengabdian

\section{Kegiatan Penyuluhan}

Kegiatan penyuluhan koperasi oleh Dinas Koperasi dan UKM Depok berlangsung pada hari Sabtu, 15 September 2018, mulai dari pukul 08.00 WIB s.d 12.00 WIB bertempat di Aula The Fin Komplek Hotel Sawangan Golf Depok. Kegiatan diikuti oleh 30 orang peserta yang terdiri dari Pembina Koperasi, Pengawas, Pengurus dan Anggota.
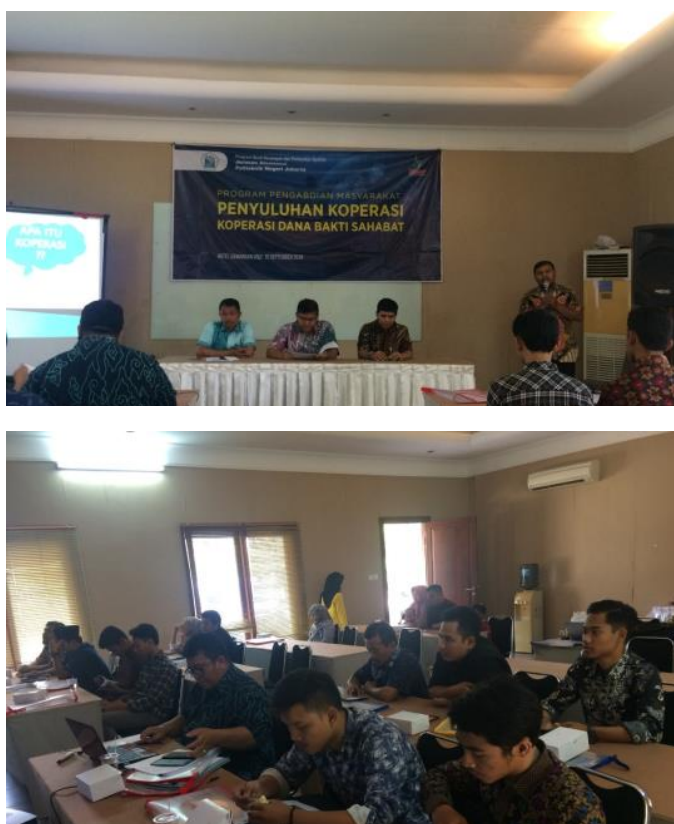

Gambar 2. Kegiatan Penyuluhan Koperasi

\section{Kegiatan Pendampingan}

Kegiatan pendampingan dalam hal ini melakukan bimbingan teknis kepada para calon pengurus dan pelaksana harian untuk mempersiapkan kebutuhan-kebutuhan pendirian KSPPS. Pendampingan yang telah dilaksanakan adalah menyusun draft akta notaries, yang berisi diantaranya berita acara rapat pendirian, absensi anggota beserta tanda tangannya, tanda pengenal anggota (KTP), bukti bayar simpanan pokok dan simpanan wajib, surat kuasa pengurusan pendirian koperasi, laporan cash flow, dan notulensi rapat pendirian.

Selain pendampingan tersebut di atas, juga dilaksanakan pendampingan penyusunan anggaran dasar dan anggaran rumah tangga Koperasi Dana Bakti Sahabat.

\section{Hasil Kegiatan}

\section{Hasil Pelatihan}

Berdasarkan hasil pengamatan, tanya jawab langsung dengan peserta, dan diskusi saat kegiatan penyuluhan koperasi telah memberikan hasil yang cukup baik untuk perkembangan pendirian Koperasi Dana Bakti Sahabat, diantaranya:

1. Memberikan pengetahuan dan pemahaman peserta penyuluhan tentang koperasi dan koperasi simpan pinjam dan pembiayaan syariah. Perbedaan secara prinsip antara koperasi syariah dan koperasi 
konvensional, khususnya dalam pengurusan pendirian dan komponen yang dibutuhkan dalam pendirian.

2. Meningkatkan semangat dan motivasi peserta untuk segera mewujudkan akta notaries dan legalitas koperasi syariah pada Komunitas Bakti Sahabat. Terutama segera terwujudnya harapan besar mereka, yaitu meminimalisir dan menghilangkan rentenir yang menjerat sebagian besar masyarakat di lingkungan Komunitas Bakti Sahabat.

\section{Hasil Pendampingan}

Dari kegiatan pendampingan secara teknis pelaksanaan pendirian KSPPS ini telah dihasilkan:

1. Draft akta notaris Koperasi Dana Bakti Sahabat beserta nomor registrasi pada Kementerian Koperasi dan UKM.

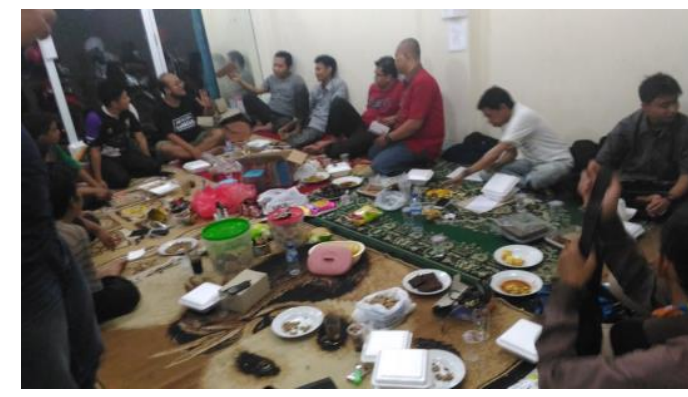

Gambar 3. Penyusunan Draft AD/ART

\section{KESIMPULAN}

Pelaksanaan pengabdian masyarakat dalam bentuk pendampingan pendirian koperasi ini sangat tepat. Dimana program ini sangat membantu terlaksananya pendirian koperasi. Kegiatan yang diawali dengan penyuluhan tentang koperasi kemudian dilanjutkan dengan pendampingan penyusunan draft legalitas koperasi, penyusunan anggaran dasar dan anggaran rumah tangga, serta pendampingan ke

\section{Ucapan Terima Kasih}

Dalam pelaksanaan pengabdian banyak pihak yang terlibat, baik dari teman-teman dosen, mahasiswa, dan pengurus koperasi Dana Bakti Sahabat. Ucapan terima kasih kami sampaikan kepada para pihak yang membantu
2. Draft AD-ART Koperasi Dana Bakti Sahabat yang nantinya akan disahkan beserta Akta Notaris.

\section{Hambatan Kegiatan}

Kegiatan penyuluhan dan pendampingan pendirian koperasi Dana Bakti Sahabat telah berjalan dengan baik. Motivasi anggota terpicu untuk menyegerakan terbitnya legalitas koperasi sebagai dasar operasional koperasi. Meskipun demikian kegiatan pendapingan ini tidak berjalan sempurna. Terdapat beberapa hambatan yang mengganggu selama berjalannya pendampingan.

Hambatan tersebut adalah faktor waktu. Kesibukan pengurus koperasi dan anggota koperasi sedikit menghambat jalannya pendampingan. Hambatan yang di maksud terjadinya beberapa kali penjadwalan ulang kegiatan sosialisasi, penyuluhan koperasi, dan pendaftaran ke notaris. notaris memudahkan bagi komunitas bakti sahabat untuk mewujudkan terbentuknya koperasi yang mereka cita-citakan.

Pada awalnya mereka kebingungan dalam langkah-langkah pendirian koperasi, dengan adanya pendampingan pendirian dari Prodi Keuangan dan Perbankan Syariah, rencana pendirian dapat dilaksanakan lebih cepat.

terlaksananya pengabdian dengan lancar. Terima kasih kami sampaikan kepada P3M PNJ yang telah memberikan dananya untuk terlaksananya kegiatan. Terima kasih kepada para pimpinan PNJ, Direktur beserta Para Wakil Direktur, Kepada Ketua Jurusan Akuntansi, dan Kepada Kaprodi Keuangan dan Perbankan Syariah. 


\section{DAFTAR PUSTAKA}

Buchori, Nur S, Koperasi Syariah. Sidoarjo: Masmedia Buana Pustaka, 2009

Pachta, Andjar W, Hukum Koperasi di Indonesia: Pemahaman Regulasi, Pendirian dan Modal Usaha, Jakarta: Kencana, 2005 